\title{
Double jeopardy: assessing the association between internal displacement, housing quality and chronic illness in a low-income neighborhood
}

\author{
Rima R. Habib • Nasser Yassin • Joly Ghanawi • \\ Pascale Haddad $\cdot$ Ziyad Mahfoud
}

Received: 6 May 2010 /Accepted: 24 September 2010 /Published online: 6 November 2010

(C) The Author(s) 2010. This article is published with open access at Springerlink.com

\begin{abstract}
Purpose This study analyzed associations between warrelated internal displacement, housing quality and the prevalence of chronic illness in Nabaa, a low-income neighborhood on the outskirts of Beirut, Lebanon.

Methods A cross-sectional survey of sociodemographics, household characteristics and health conditions of the study population was carried out in 2002. Using a structured questionnaire, the research team surveyed 1,151 households representing 4,987 residents of all ages. The survey was administered to a proxy respondent from each household in face-to-face interviews. A multiple logistic regression model using the generalized estimation equation method was constructed to assess the simultaneous effect of displacement and housing quality on reported ill health, while adjusting for potential confounders.

Results Housing quality and internal displacement were strongly associated with occurrences of chronic illness. The most vulnerable respondents were older residents, females and internally displaced people, who reported high rates of chronic illnesses. Residents with high levels of education were less likely to report a chronic illness than those that had elementary education or less.

Conclusion Nabaa residents' experience of poor health was associated with inadequate housing quality. Moreover, residents who have been displaced experience worse living conditions and were more likely to experience poor health than those who were not displaced. These results reveal a need for policies to improve housing quality and alleviate war-related consequences in low-income neighborhoods.
\end{abstract}

R. R. Habib $(\triangle) \cdot$ N. Yassin · J. Ghanawi · P. Haddad •

Z. Mahfoud

Faculty of Health Sciences, American University of Beirut, P.O. Box 11-0236, Riad El Solh 1107 2020, Beirut, Lebanon

e-mail: rima.habib@aub.edu.lb
Keywords Housing quality · Domestic environment . Internal displacement . Chronic illness .

Low-income neighborhood

\section{Introduction}

Over the past decade, research interest has increased in exploring various environmental factors affecting the health of urban dwellers. Research-based evidence shows that health is affected by personal characteristics as well as by the living environment, including housing and surroundings (Diez Roux 2001; Pickett and Pearl 2001; Riva et al. 2007; Macintyre et al. 2008; Muhajarine et al. 2008; Poortinga et al. 2008). Adequate housing conditions are important for the physical and psychosocial well-being of individuals (Lawrence 2006). Despite methodological difficulty in establishing a direct association between housing quality and health, research is increasingly demonstrating that poor housing conditions have negative impacts on health (Lowry 1991; Bonnefoy et al. 2003; Shaw 2004; WHO 2004; Bonnefoy 2007; Habib et al. 2006, 2009; Harpham 2009; Jacobs et al. 2009; Jia et al. 2009). Moreover, povertystricken individuals are more likely to experience a heavier burden of illness and are prone to live in more inadequate housing conditions and neighborhoods compared to their counterparts (Illsley and Svensson 1990; Bonnefoy 2007; Poortinga et al. 2008).

A number of inadequate housing conditions, such as dampness and the presence of molds, have been associated with respiratory ailments in children and adults (Zock et al. 2002; Spengler et al. 2004). Crowding is linked to increased spread of infectious diseases (Baker et al. 2000; Krieger and Higgins 2002). Other associations found between the built environment and health include pest 
infestations, which often have been associated with allergies (Phipatanakul et al. 2000; Wang et al. 2008), and indoor thermal comfort (cold or hot), which is associated with increased risk of cardiovascular health problems (Collins 1986). Poor indoor air quality has been linked with asthma and other chronic respiratory diseases (Krieger and Higgins 2002; Bonnefoy 2007; Jacobs et al. 2009). Furthermore, poor housing and adverse health conditions are exacerbated in contexts of armed conflict. Evidence from war zones shows that armed conflicts lead to a range of direct and indirect adverse health conditions (Pederson 2002). Roberts and colleagues report that deprivation of basic services and supplies, and exposure to traumatic events such as war had a negative impact on the physical and mental health of internally displaced persons in northern Uganda (Roberts et al. 2009). Often people are displaced to overcrowded settlements or neighborhoods that have poor sanitation, water services, electricity and housing quality, conditions that may increase the occurrence of diseases (Ghobarah et al. 2004; Shaw 2004). The health impacts of conflict are very likely to linger for long periods after the conflicts cease (Ghobarah et al. 2004).

Lebanon has suffered from protracted civil conflict (1975-1990) and from Israeli invasions in 1978, 1982 and 2006. Wars have resulted in damaged infrastructures and severe social, economic and health impacts. Furthermore, wars have led to the displacement of approximately 1 million people, of which 450,000 have been displaced internally (USCRI 1999). Most of the internally displaced people have settled in urban areas. Internal displacement compounded with rapid urban growth has led to the formation of a number of informal and unregulated settlements on the outskirts of the capital, Beirut (UN 2008). This article investigates the association between internal displacement, housing quality and reported chronic diseases in a low-income neighborhood located on the outskirts of Beirut, Lebanon. It considers the health consequences of war-related internal displacement and poor housing conditions.

\section{Context}

The study was undertaken in the neighborhood of Nabaa in eastern Beirut, a densely populated urban area that has grown exponentially on the edge of the capital city. The neighborhood has an estimated population of about 12,000, with one-third being internally displaced from other parts of the country (Makhoul et al. 2003). It falls under two municipal authorities: Bourj Hammoud and Sin El-Fil. It is the nearest settlement to Municipal Beirut and is only $5 \mathrm{~km}$ from the city's business district (see Fig. 1). Drawing the borders of the area is problematic because of the lack of clear municipal zoning of neighborhoods and quarters. Although geographic and physical boundaries are blurred, it is socially well defined as a low-income, densely populated and working class area at the edge of the city center. The neighborhood has an additional feature associated with warrelated displacement. The neighborhood has housed waves of internally displaced people.

The area was originally agricultural and comprised of marshland at the eastern bank of the Beirut River. The land is mostly owned by Christian families from the village of Sin el-Fil and nearby villages who use it for farming. Christians settled in the area in the mid-nineteenth century, migrating from villages in Mount Lebanon (Khater 2001). The presence of the Maronite Kahale family in Sin El-Fil, for example, dates to 1860; they originated from the Aley district in Mount Lebanon.

In 1926, however, a major change in the local fabric took place when Armenian refugees, who fled persecution in Turkey, moved to settle in the area with the help of French Mandate authorities and charities. The Armenians, estimated at 10,000 migrants, were relocated from temporary camps to permanently and purposely built houses on the western side of the area, which became known as Bourj Hammoud (Sharara 1998; Fawaz and Peillen 2003). In 1939, with the arrival of another wave of Armenian refugees from Alexandretta (South Turkey), more houses were built and the area extended further.

The 1940s and 1950s saw another wave of newcomers from peripheral parts of Lebanon. With the acceleration of urbanization in the 1940s and growth of Beirut as the country's main economic and political center, the area attracted waves of low-skilled rural migrant job seekers, especially Shia Muslims. Many of the Shias moved from villages and towns of South Lebanon in the wake of the 1948 Israeli-Arab war that led to cutting the economic ties between Southern Lebanon and Mandate Palestinian cities.

Over time, the neighborhood emerged as a confessionally mixed working class area housing waves of economic migrants, refugees and internally displaced people. Until the mid-1970s, the area was populated with Shia Muslims, Armenian Christians and Maronite Christians. But with collective violence erupting in 1975-1977 (El-Khazen, 2000), the communal fabric of the area underwent a major change. Civil war led to the displacement of almost all the Muslim population from the neighborhood. Conversely, Christians who were displaced from other parts of the country moved into the neighborhood, replacing Muslim residents. The change in the communal demographics of the area persisted even after the end of the civil war in 1990.

\section{Housing conditions in Nabaa}

The rapid growth of the neighborhood was a result of the surge in housing demand as waves of refugees, internally 
Fig. 1 Eastern suburbs. The Beirut River acts as the border between municipal Beirut and the eastern suburb. Nabaaa is within the blue line. Source: Municipality of Beirut website

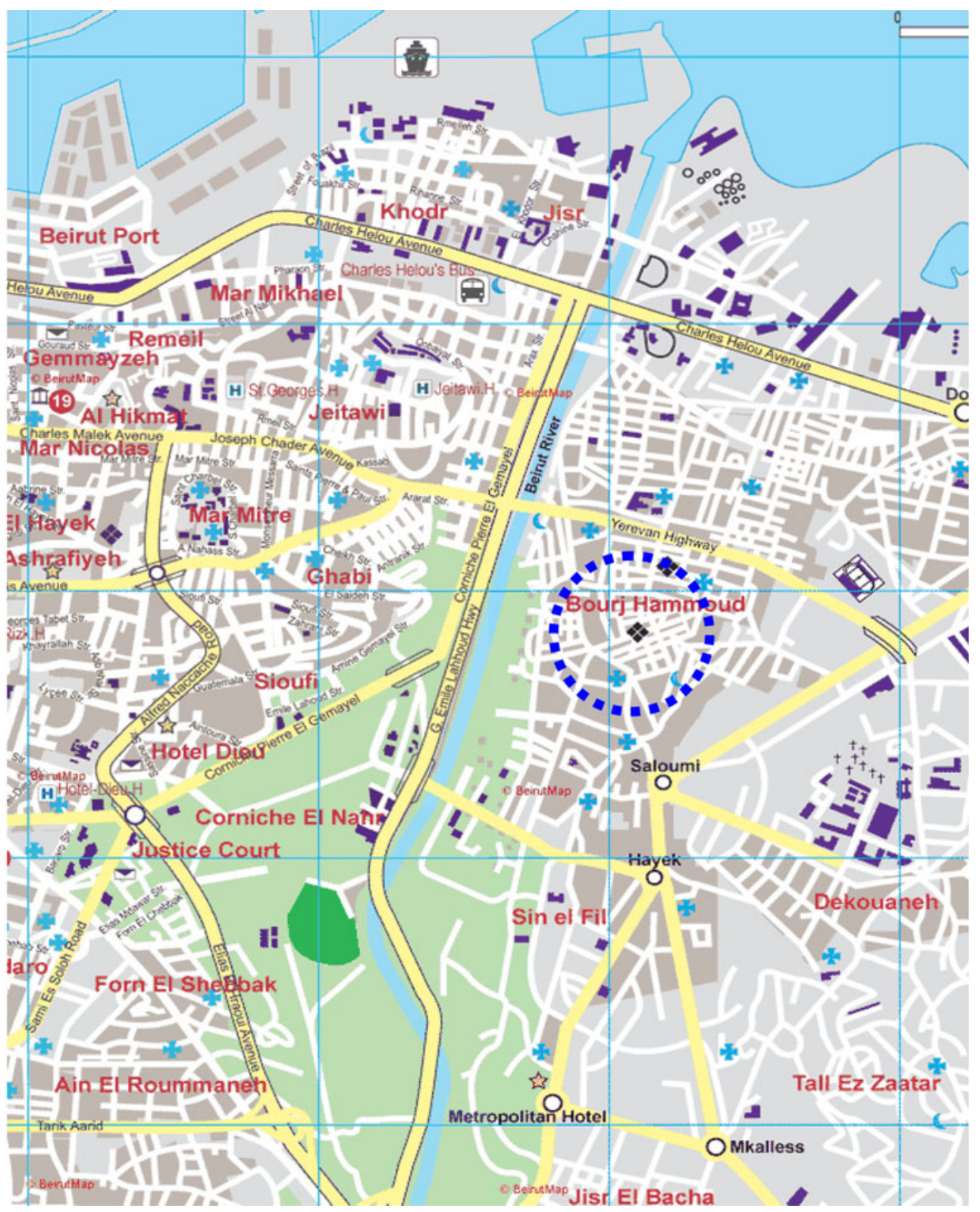

displaced and rural migrants were attracted to Nabaa because of its proximity to industrial plants and Beirut's business district. Indeed, the affordability of land and housing due to the unregulated urban system was central in luring newcomers. The land was bought in small parcels, and dwellings were hastily built by those who had some savings in an attempt to make a quick profit from the housing demand. The size of the newly built apartments was between 100-150 $\mathrm{m}^{2}$. Buildings were between two or three floors high, and ground floors were usually left for commercial and industrial purposes and were used as grocery shops, shoemaking shops or car repair centers (see Figs. 2, 3, 4). Although building permits were obtained from the municipal authorities, the buildings were poorly constructed with precarious housing and environmental conditions.

\section{Methods}

Design and data collection

This study is based on data obtained from the Urban Health Study carried out in 2002 by the Faculty of Health Sciences at the American University of Beirut. A cross-sectional survey design was used in the Nabaa neighborhood. The survey was based on a two-stage probability sample of 1,151 households with 4,987 members of all age groups.

A questionnaire was administered to a proxy respondent from the household in a face-to-face interview. The questionnaire included questions on socio-demographic information and health of participants, as well as household characteristics. The interviewers who administered the 
Fig. 2 Image of mixed housing and industrial use; residential units above car repair workshops in Nabaa

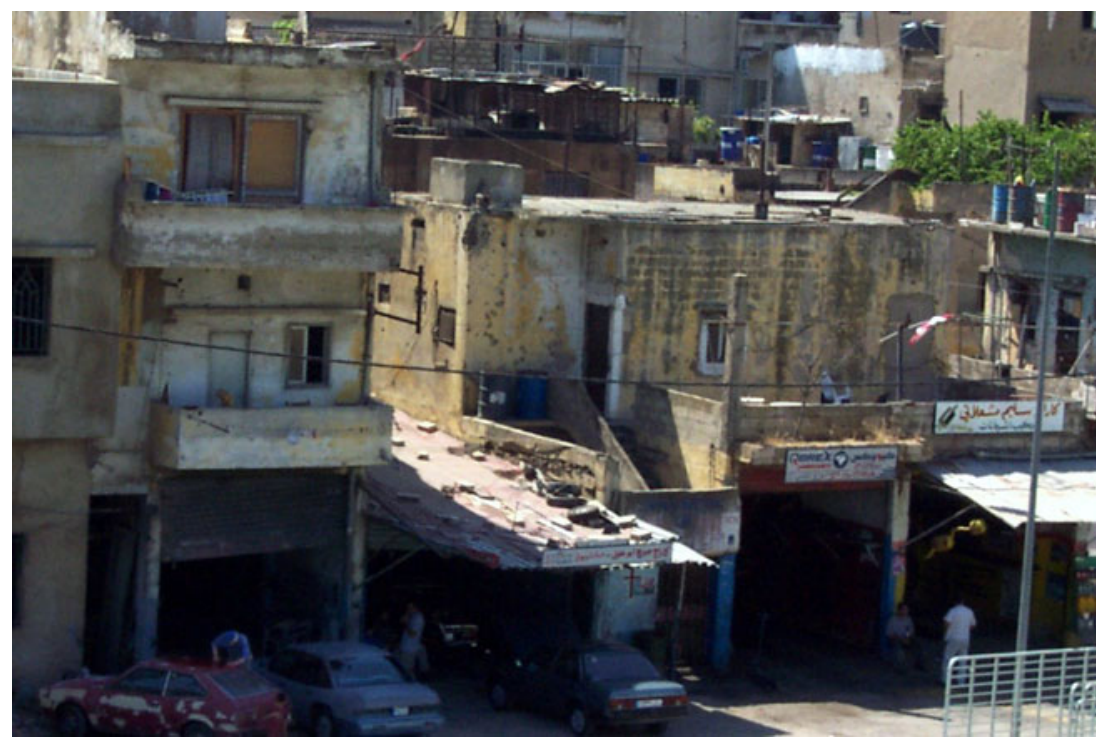

questionnaires were thoroughly trained on individual questions. The instrument was pilot tested to insure respondents' proper understanding of all questions.

Ethical approval for the study was granted by the Institutional Review Board at the American University of Beirut. All respondents were informed of the objective of the study, and oral consent was obtained. The overall response rate was $83.4 \%$.

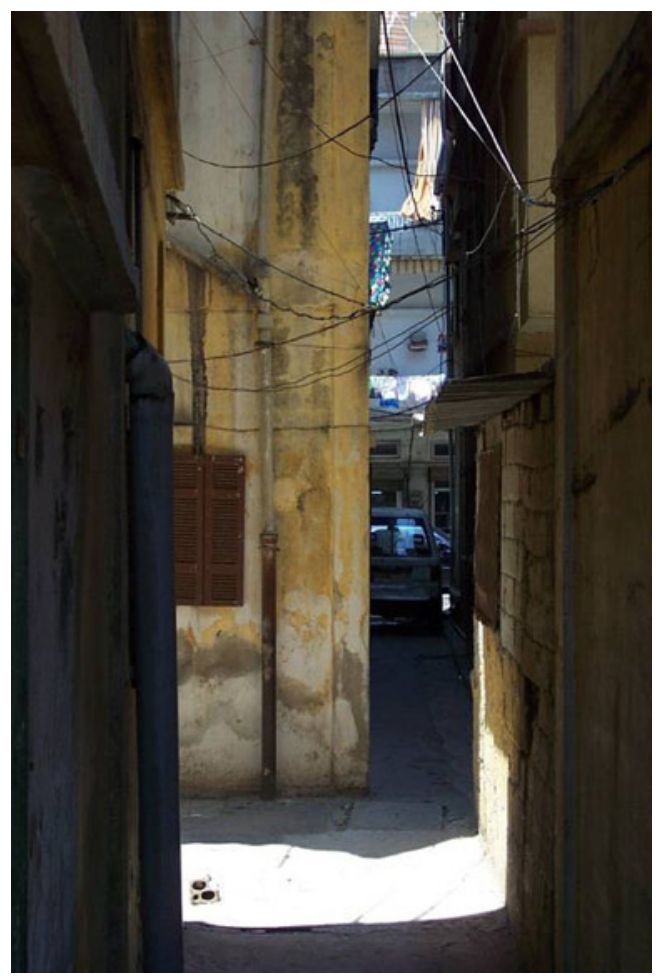

Fig. 3 Narrow streets in Burj Hammoud-Sin el Fil

\section{Measures}

Demographic and socioeconomic characteristics

The sociodemographic economic variables such as age and gender of each household member, as well as measures of educational attainment of head of household/spouse and monthly income, were included in the analysis. Age of

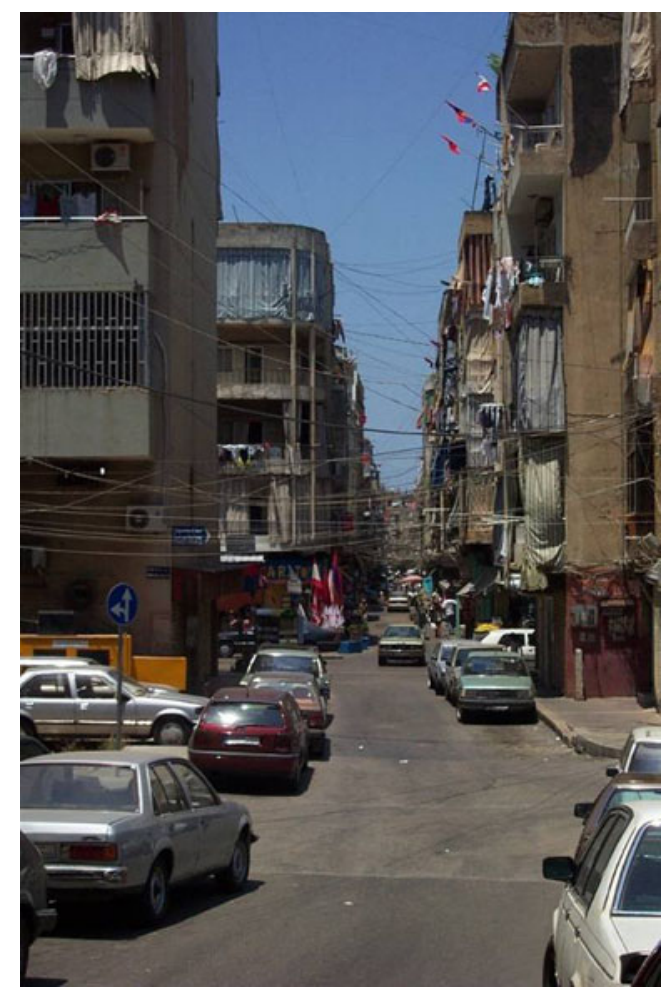

Fig. 4 A main road in Burj Hammoud-Sin el Fil 
respondents was subdivided into three categories: youth $(0-$ 17 years), adults (18-59 years) and older adults (60+ years). The educational attainment was estimated using the maximum number of years recorded for the head of the household or his/her spouse; it was then divided into three groups: elementary or less, primary-intermediate, and secondary or above. The household income, measured as total monthly income in thousands of Lebanese pounds (LBP), was divided into six groups: $<450,000$ LBP $(<\$$ US 300 ); 450,000-<750,000 LBP (US\$ 300-<500); 750,000$<1,000,000$ LBP $(\$ 500-<667) ; 1,000,000-<1,200,000$ $(\$ 667-<800) ; 1,200,000-<2,000,000 \quad(\$ 800-<1,333)$; $\geq 2,000,000$ ( $\geq \$ 1,333)$. Furthermore, displacement was measured by asking respondents whether or not they had ever been displaced (yes or no).

Measurement of crowding was calculated by dividing the number of people living in each household by the number of rooms in the dwelling. Households were divided into two categories: moderately crowded with two persons or less per room and highly crowded with more than two persons per room. All rooms in the dwelling were counted except the kitchen, bathroom, unclosed balconies and garages.

\section{Measures of housing quality}

This study used indicators of housing quality that measure infrastructure and services in addition to housing conditions. The infrastructure and services index comprised six items that included: cuts in electrical power for more than 4 $\mathrm{h} /$ day, problems with the reliability of electrical power, problems with the timing of garbage collection, problems with garbage disposal, problems with sewage disposal and rainwater flooding. An item regarding drinking water was excluded from the calculation because all households reported access to potable water. The housing conditions index included 15 items regarding pest infestation, lighting, natural ventilation, heating, presence of humidity, and cracks in walls and ceiling (see Table 3). The perception of residents, who are well aware of the environmental conditions of their households and neighborhood, was used to assess the quality of infrastructure, services and housing conditions.

All the items in both indices were dichotomized such that zero denoted the absence of a problem and one denoted its presence. The number of problems were tallied and reflected in a score ranging from 0 to 15 problems for the housing conditions index and 0 to 6 for the infrastructure and services index.

\section{Outcome measure}

Reported chronic illness was the outcome of interest in this study. The indicator was dichotomized into 'zero,' denoting the absence of chronic illness, and 'one,' indicating its presence. A proxy respondent reported on chronic illnesses prevalent among household members using a checklist included in the questionnaire. They also provided additional information on other illnesses where applicable. Chronic illnesses were classified and identified using the 10th revised edition of the International Classification of Diseases (WHO 1992).

\section{Statistical analysis}

Sample characteristics, such as demographic variables, type of reported illnesses and housing quality indices were summarized using means and standard deviations for continuous variables and frequency distributions for categorical variables. These variables were also compared between those who were ever displaced and those who were not using the chi-square test, Fisher's exact test when cell counts were less than five and t-test for continuous variables (Infrastructure and Services Index and Housing Conditions Index). We used a multiple regression model to study the simultaneous effect of displacement and housing quality on reported chronic illness, adjusting for possible confounders such as demographic variables. The generalized estimation equation method was used to account for correlations among people living in the same household. This was done by including all variables that were significant $(p \leq 0.05)$ at the bivariate level. Adjusted odds ratios (OR) and corresponding 95\% confidence intervals were reported. All analyses were done using STATA (version 10, College Station, TX). Significance was set at the $5 \%$ level.

\section{Results}

Sociodemographics and health profile

Basic sociodemographics of the sample population $(\mathrm{N}=$ $4,987)$ in Nabaa are summarized in Table 1. Residents in Nabaa were predominantly Lebanese $(91.3 \%)$, with a mean age of 30 ( $\mathrm{SD} \pm 19.7$, range $0-97$ years) and gender ratio of 1 . Over half $(55 \%)$ of the residents were single, and 38\% reported being married. Over a third $(35 \%)$ of residents reported having ever been displaced. As for the place of origin, the majority $(80 \%)$ of residents reported originating from outside the Beirut area. For most of the residents, the places of origin were Mount Lebanon (34\%) and Bekaa (17\%). Only $46 \%$ of those aged 15 years or more were involved in the labor force. Over half $(59 \%)$ of the residents earned less than 1,000,000 LBP (US\$ $667)$ a month. Nearly two-thirds of the residents reported low educational attainment: $68 \%$ had elementary educa- 
Table 1 Sociodemographic characteristics of study participants $(\mathrm{N}=$ 4,987, Nabaa 2002)

\begin{tabular}{|c|c|c|}
\hline Independent variable & $N$ & Percentage \\
\hline Study population & 4,987 & 100 \\
\hline \multicolumn{3}{|l|}{ Age } \\
\hline$<18$ & 1,572 & 31.5 \\
\hline $18-59$ & 2,895 & 58.1 \\
\hline $60+$ & 519 & 10.4 \\
\hline Mean age (SD) & $30.27 \pm 19.74$ & \\
\hline \multicolumn{3}{|l|}{ Gender } \\
\hline Male & 2,485 & 49.8 \\
\hline Female & 2,502 & 50.2 \\
\hline \multicolumn{3}{|l|}{ Marital status } \\
\hline Single & 2,720 & 54.6 \\
\hline Engaged & 67 & 1.3 \\
\hline Married & 1,905 & 38.2 \\
\hline Widowed & 231 & 4.6 \\
\hline Divorced/separated & 61 & 1.2 \\
\hline \multicolumn{3}{|l|}{ Nationality } \\
\hline Lebanese & 4,551 & 91.3 \\
\hline Other (Palestinians: $n=69$ ) & 436 & 8.7 \\
\hline \multicolumn{3}{|l|}{ Place of origin } \\
\hline Beirut & 596 & 12.0 \\
\hline Mount Lebanon & 1,669 & 33.5 \\
\hline North Lebanon & 560 & 11.2 \\
\hline South Lebanon & 558 & 11.2 \\
\hline Bekaa & 856 & 17.2 \\
\hline Nabatieh & 358 & 7.2 \\
\hline Other countries & 390 & 7.8 \\
\hline \multicolumn{3}{|l|}{ Place of origin (re-categorized) } \\
\hline Beirut Governorate & 596 & 12.0 \\
\hline Other Lebanese governorates & 4,001 & 80.2 \\
\hline Other countries & 390 & 7.8 \\
\hline \multicolumn{3}{|l|}{ Income level } \\
\hline$<450,000$ & 180 & 18.0 \\
\hline $450,000-<750,000$ & 272 & 27.3 \\
\hline $750,000-<1,000,000$ & 135 & 13.5 \\
\hline $1,000,000-<1,200,000$ & 111 & 11.1 \\
\hline $1,200,000-<2,000,000$ & 221 & 22.1 \\
\hline$\geq 2,000,000$ & 79 & 7.9 \\
\hline \multicolumn{3}{|l|}{ Ever displaced } \\
\hline Yes & 1,736 & 34.8 \\
\hline No & 3,240 & 65.0 \\
\hline Do not know & 11 & 0.2 \\
\hline \multicolumn{3}{|c|}{ Highest educational level of head of household/spouse } \\
\hline Elementary or less & 782 & 68.4 \\
\hline Primary-intermediate & 209 & 18.3 \\
\hline Secondary or more & 152 & 13.3 \\
\hline \multicolumn{3}{|l|}{ Labor force participation ${ }^{\mathrm{a}}$} \\
\hline No & 1,727 & 46.4 \\
\hline Yes & 1,991 & 53.6 \\
\hline \multicolumn{3}{|l|}{ Household crowding } \\
\hline Two persons or less in a room & 2,987 & 60.1 \\
\hline More than two persons in a room & 1,985 & 39.9 \\
\hline
\end{tabular}

${ }^{\mathrm{a}}$ Limited to members aged $\geq 15$ years old tion or less, $18 \%$ had primary-intermediate, and only $13 \%$ had secondary or more. As for crowding, $40 \%$ of the residents lived in households with more than two persons per room.

Around $20 \%$ of residents reported suffering from a chronic illness (Table 2). The main chronic illnesses reported were circulatory $(27 \%)$, endocrine nutritional and metabolic $(20 \%)$, musculoskeletal $(14 \%)$ and respiratory $(13 \%)$.

Housing quality indices

Table 3 shows the proportion of households that reported problems in their housing quality. The most common reported problems relating to infrastructure and services were power cuts $(46 \%)$ followed by problems with sewage disposal $(31.5 \%)$, unreliability of electrical power $(24.1 \%)$, and problems with garbage disposal (21\%) and garbage collection (19\%). Only $9 \%$ of the households reported problems due to rainwater flooding. The most prevalent problems related to housing conditions were poor ventilation $(90 \%)$, cockroach infestation $(72 \%)$, lack of a main source of heating (71\%), seepage in walls (64\%) and ceilings (42\%) and humid conditions (59\%). Nearly half $(45 \%)$ of the households reported cracks in the walls.

Sociodemographics and displacement

Table 4 presents the sociodemographics of the displaced group $(\mathrm{N}=1,736)$ compared to the non-displaced group $(\mathrm{N}=3,240)$. The displaced group was older, with a majority (73\%) aged between 18 and 59 years old, whereas only $50 \%$ of the non-displaced persons were in this age group. Nearly one in five persons $(18 \%)$ of the displaced group was above 59 years of age as compared to only $6.5 \%$ of the non-displaced. There were no differences in gender proportions in both groups. The majority (97\%) of the displaced were Lebanese. The study participants' places of origin were mainly Mount Lebanon (38\%), Bekaa Valley (20\%) and South Lebanon $(15 \%)$. No differences related to the labor force were found between the displaced and non-displaced groups. Overall, the income level for both groups was similar. Nearly $42 \%$ of the non-displaced group lived in households with more than two persons in a room compared to $37 \%$ for the displaced group. Finally, on average the displaced groups reported a significantly lower number of problems with infrastructure and services (1.47 vs. 1.57 for displaced and non-displaced groups, respectively) but a higher number of problems with housing conditions (6.54 vs. 6.23 for displaced and non-displaced groups, respectively). 
Table 2 Type of reported illnesses among study participants (Nabaa, 2002)

\begin{tabular}{lll}
\hline Independent variable & $N$ & Percentage \\
\hline Reporting a chronic illness & & \\
Yes & 966 & 19.4 \\
No & 4,021 & 80.6 \\
Total number of individuals & 4,987 & 100 \\
Number of reported chronic illnesses per household & & \\
0 & 526 & 45.7 \\
1 & 376 & 32.7 \\
$\geq 2$ & 249 & 21.6 \\
Total number of households & 1,151 & 100.0 \\
Type of reported chronic illnesses & & \\
Neoplasms & 9 & 0.9 \\
Diseases of the blood & 33 & 3.4 \\
Endocrine nutritional and metabolic diseases & 188 \\
Mental and behavioral problems & 9 & 0.9 \\
Nervous system & 77 & 8.0 \\
Diseases of the eye & 11 & 1.1 \\
Diseases of the ear & 2 & 0.2 \\
Diseases of the circulatory system & 265 & 27.4 \\
Diseases of the respiratory system & 124 & 12.8 \\
Diseases of the digestive system & 51 & 5.3 \\
Diseases of the skin and subcutaneous tissue & 6 & 0.6 \\
Diseases of the musculoskeletal system & 135 \\
Diseases of the genitourinary system & 36 \\
Symptoms, signs of abnormal clinical and laboratory findings & 13 \\
Not specified & 7 & 14.0 \\
Total number of reported chronic illnesses & 966 \\
\hline & & 0.7 \\
\hline & & 100.0 \\
\hline
\end{tabular}

Association between housing quality indices and chronic illnesses

Results of the multiple logistic regression model (Table 5) demonstrated that reporting chronic illness increased significantly with displacement, the number of infrastructure and housing problems, age, and gender, whereas it decreased significantly with household educational attainment. Residents who are 60 years of age and over were 24 times more likely to report chronic illnesses compared with those aged less than 18 years $(\mathrm{OR}=24.61,95 \%$ CI $18.07-$ 33.52). Similarly, female residents were 40 percent more likely to report a chronic illness than males $(\mathrm{OR}=1.40,95 \%$ CI 1.21-1.63). Individuals who had ever been displaced were 44 percent more likely to report a chronic illness than those who had never been displaced $(\mathrm{OR}=1.44,95 \% \mathrm{CI}=1.21-$ 1.73). Households with a head or spouse with a secondary education or more were 28 percent less likely to report chronic illness than households with a head or spouse with only an elementary education $(\mathrm{OR}=0.72,95 \%$ CI $0.53-0.98)$.

For each additional problem reported concerning the infrastructure and services, the presence of illness increased by $9 \%(\mathrm{OR}=1.09,95 \% \mathrm{CI} 1.01-1.18)$. Similarly, for each additional problem reported in housing conditions, the presence of illness increased by $5 \%(\mathrm{OR}=1.05,95 \% \mathrm{CI}$ 1.02-1.09). No significant association was found between the presence of chronic illnesses and crowding conditions.

\section{Discussion}

The study investigated the association between the domestic environment, internal displacement and prevalence of chronic illnesses in a low-income urban neighborhood on the outskirts of Beirut. One fifth of the population reported suffering from chronic diseases, including circulatory, endocrine, nutritional and metabolic illnesses, in addition to musculoskeletal and respiratory problems. We found a strong positive association between housing quality and the occurrence of chronic illnesses. This result echoed findings of other studies carried out in Lebanon in the suburb of Hay el Sellom, the largest informal settlement in Beirut (Habib et al. 2009), and in Palestinian refugee camps in Lebanon (Habib et al. 2006; Zabaneh et al. 2008). Furthermore, we found higher rates of chronic illnesses reported among females, older people and internally displaced individuals. Moreover, residents that had 
Table 3 Frequency distribution of the housing quality indices (Nabaa, 2002)
No. of households reporting

Percentage presence of a problem

\begin{tabular}{lll} 
Measures of infrastructure and services & & \\
Cuts in electrical power for more than 4 h/day & 531 & 46.1 \\
Problems with sewage disposals & 362 & 31.5 \\
Problems with garbage disposal & 243 & 21.1 \\
Problems with the reliability of electrical power & 277 & 24.1 \\
Problems with timing of garbage collection & 221 & 19.2 \\
Rainwater flooding & 108 & 9.4 \\
Measures of housing conditions & & \\
Poor ventilation & 1,030 & 89.5 \\
Cockroach infestation & 833 & 72.4 \\
Absence of a main source of heating & 812 & 70.5 \\
Presence of seepage in walls & 741 & 64.4 \\
Presence of humidity & 682 & 59.3 \\
Presence of cracks in walls & 513 & 44.6 \\
Presence of seepage in ceiling & 480 & 41.7 \\
Lack adequate natural sunlight in bedroom & 336 & 29.2 \\
Lack adequate natural sunlight in living room & 300 & 26.1 \\
Presence of cracks in ceiling & 317 & 27.5 \\
Presence of broken windows & 258 & 22.4 \\
Presence of water overflow from floor drains & & \\
Always & 52 & 4.5 \\
Most of the time & 34 & 3.0 \\
Sometimes & 169 & 14.7 \\
Mice infestation & 264 & 22.9 \\
Rat infestation & 133 & 13.6 \\
Presence of exposed electrical wires & 150 & \\
\hline & & \\
& &
\end{tabular}

high educational attainment were less likely to report a chronic illness than those that had elementary education or less.

\section{Domestic environment and health}

In accordance to findings of previous studies, our analysis showed a positive association between problems in infrastructure and services and the prevalence of chronic illnesses (Bitran et al. 2003; Leipziger et al. 2003; Bailie and Wayte 2006). The most prevalent reported problems in infrastructure and services, relating mainly to electrical power and sewage and garbage disposal, were an expected result. As a result of the civil war, power cuts have been common throughout the country, with increased frequency in impoverished areas (Habib et al. 2006, 2009). Some households rely on private electricity services operated by local electrical generators, adding a financial burden to the household (Fawaz 2008; Habib et al. 2009). Moreover, limited investment in proper sewage networks has led to sewage overflow in underserved areas. Similarly, garbage collection and disposal services have not been satisfactory in low income neighborhoods, leading to quick over-piling of solid wastes on street corners.
In addition to infrastructure-related problems, residents suffered from poor housing conditions such as poor ventilation, cockroach infestation, seepage, humidity and lack of heating. Our analysis showed a positive association between housing conditions and the presence of chronic illnesses in the study population. It has been reported that poor ventilation increases the interior moisture of the house, resulting in a thriving environment for pests such as cockroaches, which have been linked to human respiratory diseases (Krieger and Higgins 2002).

Although $40 \%$ of the households in Nabaa reported living in crowded conditions with more than two persons per room, the regression analysis did not show an association between household crowding and the presence of chronic illness. This result can be attributed to the high collinearity between the measure used for crowding conditions and housing conditions $(p<0.001)$ and infrastructure and services $(p<0.001)$.

\section{Displacement and health}

Our findings showed that the displaced group was older and had lower educational attainment than the non-displaced 
Table 4 Sociodemographics of the displaced group as compared to the non-displaced group $(\mathrm{N}=4,987$, Nabaa, 2002)

\begin{tabular}{|c|c|c|c|}
\hline Variables & Displaced N (\%) & Not displaced N (\%) & $P$-value \\
\hline Age & & & $<0.001$ \\
\hline$<18$ & $168(9.7)$ & $1,404(43.2)$ & \\
\hline $18-59$ & $1,258(72.5)$ & $1,637(50.4)$ & \\
\hline $60+$ & $309(17.8)$ & $210(6.5)$ & \\
\hline Gender & & & 0.286 \\
\hline Male & $883(50.9)$ & $1,602(49.3)$ & \\
\hline Female & $853(49.1)$ & $1,649(50.7)$ & \\
\hline Nationality & & & $<0.001$ \\
\hline Lebanese & $1,685(97.1)$ & $2,866(88.2)$ & \\
\hline Other & $51(2.9)$ & $385(11.8)$ & \\
\hline Place of origin & & & $<0.001$ \\
\hline Beirut & $139(8.0)$ & $457(14.1)$ & \\
\hline Mount Lebanon & $658(37.9)$ & $1,011(31.1)$ & \\
\hline North Lebanon & $148(8.5)$ & $412(12.7)$ & \\
\hline South Lebanon & $262(15.1)$ & $296(9.1)$ & \\
\hline Bekaa & $341(19.6)$ & $515(15.8)$ & \\
\hline Nabatieh & $159(9.2)$ & $199(6.1)$ & \\
\hline Other countries & $29(1.7)$ & $361(11.1)$ & \\
\hline Labor force participation $^{*}$ & & & 0.055 \\
\hline No & $907(55.3)$ & $1,084(52.1)$ & \\
\hline Yes & $733(44.7)$ & $995(47.9)$ & \\
\hline $\begin{array}{l}\text { Highest educational level of head } \\
\text { of household/spouse }\end{array}$ & & & 0.009 \\
\hline Elementary or less & $1,227(71.2)$ & $2,169(67.0)$ & \\
\hline Primary-intermediate & $295(17.1)$ & $616(19.0)$ & \\
\hline Secondary or more & $202(11.7)$ & $453(14.0)$ & \\
\hline Income level & & & $<0.001$ \\
\hline$<450,000$ & $185(12.4)$ & $406(14.1)$ & \\
\hline $450,000-<750,000$ & $333(22.4)$ & $738(25.7)$ & \\
\hline $750,000-<1,000,000$ & $189(12.7)$ & $399(13.9)$ & \\
\hline $1,000,000-<1,200,000$ & $173(11.6)$ & $341(11.9)$ & \\
\hline $1,200,000-<2,000,000$ & $393(26.4)$ & $733(25.5)$ & \\
\hline$\geq 2,000,000$ & $216(14.5)$ & $254(8.8)$ & \\
\hline Household crowding & & & 0.001 \\
\hline Two persons or less in a room & $1,097(63.2)$ & $1,890(58.4)$ & \\
\hline More than two persons in a room & $639(36.8)$ & $1,346(41.6)$ & \\
\hline Variables & Displaced mean (SD) & Not displaced mean (SD) & $P$-value \\
\hline ISI & $1.47(1.24)$ & $1.57(1.24)$ & 0.004 \\
\hline $\mathrm{HCI}$ & $6.54(2.68)$ & $6.23(2.75)$ & $<0.001$ \\
\hline
\end{tabular}

${ }^{*}$ More than 15 years old

group, indicating that the older generation did not return to their place of origin after the civil strife had ended. Furthermore, the displaced group reported more problems related to poorer housing conditions than their non-displaced counterparts. Significantly, our study indicated that the displaced group is more likely to suffer from chronic illness compared to the non-displaced. This confirms other studies conducted in war and post-war zones. Choueiry and Khawaja's (2007) assessment of the association between internal dis- placement and self-reported health of married women in three impoverished neighborhoods in Beirut showed that displaced women reported poorer self-reported health than non-displaced women. Similar studies in Bosnia and Herzegovina, Rwanda and Chechnya show that the displaced stay in camps or temporary settlements for years after conflicts end, often in precarious living conditions affecting their general health status (Ghobarah et al. 2004; de Jong et al. 2007; Schmidt et al. 2008). 
Table 5 Multiple logistic regression on the presence of chronic illnesses among study participants $(\mathrm{N}=4,987$, Nabaa, 2002)

*Significance level was set at 0.05

\begin{tabular}{llll}
\hline Independent variable & Adjusted OR & $95 \% \mathrm{CI}$ & $P$-value* \\
\hline Age & & & \\
$<18$ & 1 & $2.64-4.40$ & $<0.001$ \\
$18-59$ & 3.40 & $18.07-33.52$ & $<0.001$ \\
$60+$ & 24.61 & & \\
Gender & & & \\
Male & 1 & $1.21-1.63$ & \\
Female & 1.40 & & 0.185 \\
Nationality & & $0.53-1.10$ & \\
Lebanese & 1 & & \\
Other & 0.77 & $1.21-1.73$ & \\
Ever displaced & & & \\
No & 1 & & \\
Yes & 1.44 & 0.002 \\
Highest educational level of head of household/spouse & 1 & $0.69-1.13$ & \\
Elementary or less & 0.88 & $1.01-1.18$ & 0.316 \\
Primary-intermediate & 0.72 & $1.02-1.09$ & 0.038 \\
Secondary or more & 1.09 & & 0.028 \\
Infrastructure and Services Index & 1.05 & & \\
Housing Conditions Index & 1 & & \\
Household crowding & 0.94 & & \\
Two persons or less in a room & & & \\
More than two persons in a room & & & \\
\hline
\end{tabular}

\section{Limitations}

This study has several limitations. First, the cross-sectional design provides only descriptive relationships between variables rather than causal. Second, the current study did not include mental health evaluations of the internally displaced residents, which may be necessary, as Karam et al. (2006) report a greater prevalence of mental disorders among individuals in Lebanon who have been exposed to traumatic events such as war. Research shows that poor housing conditions are linked to negative impacts on mental health and associated with depression among residents (Krieger and Higgins, 2002; Shenassa et al. 2007). Finally, no data was collected on behavioral characteristics of participants, such as smoking, drinking and drug abuse, all of which have been strongly linked to health (Harpham 2009).

\section{Conclusion}

This study investigated the association among war-related internal displacement, housing quality and the prevalence of chronic illness in Nabaa, a low-income neighborhood in Beirut. The study shows that reported poor health conditions among residents of Nabaa were associated with poor housing quality. Moreover, residents that have ever been displaced experience worse living conditions and are more likely to report poor health than those that have never been displaced. This article highlights the lingering impact of armed conflicts on the health of war-affected populations, where the internally displaced in Lebanon still suffer from the effects of civil war twenty years after its end. This article suggests that special attention needs to be given to the internally displaced even after years of peace and settlement, and recommends that municipal authorities give special consideration to the needs of the internally displaced people when planning and implementing basic services. Furthermore, grass-root movements that represent the internally displaced and other marginalized groups should be given a platform to voice their needs when planning and carrying out environmental, public health and social services. Forms of participatory governance at the municipal level could include, but are not exclusive to forming neighborhood committees, neighborhood forums and issue-based groups.

Acknowledgements The authors thank all the participants in the study. This work was supported by the Wellcome Trust [061495/Z/00/Z], and the Mellon and Ford Foundations.

Conflict of interest The authors have no conflict of interest. 
Open Access This article is distributed under the terms of the Creative Commons Attribution Noncommercial License which permits any noncommercial use, distribution, and reproduction in any medium, provided the original author(s) and source are credited.

\section{References}

Bailie RS, Wayte K (2006) Housing and health in indigenous communities: key issues for housing and health improvement in remote Aboriginal and Torres Strait Islander communities. Aust J Rural Health 14(5):178-183

Baker $\mathrm{M}$ et al (2000) Household crowding a major risk factor for meningococcal disease in Auckland children. Pediatr Infect Dis J 19:983-990

Bitran R, Turbat V, Meessen B, Van Damme W (2003) Preserving equity in health in Cambodia: health equity funds and prospects for replication. Online journal of the World Bank Institute. World Bank, Washington, DC

Bonnefoy X (2007) A pan-European housing and health survey: description and evaluation of methods and approaches. International Journal of Environment and Pollution 30: (3/4)

Bonnefoy X, Braubach M, Moissonnier B et al (2003) Housing and health in Europe: preliminary results of a pan-European study. Am J Public Health 93(9):1559-1563

Choueiry N, Khawaja M (2007) Displacement and health status in low income women: findings from a population-based study in Greater Beirut. J Migrat Refugee Issues 3(1):1-13

Collins KJ (1986) Low indoor temperatures and morbidity in the elderly. Age Ageing 15:212-220

de Jong K, Kam S, Ford N, Hargreaves S, van Oosten R, Cunningham D, Boots G, Andrault E, Kleber R (2007) The trauma of ongoing conflict and displacement in Chechnya: quantitative assessment of living conditions, and psychosocial and general health status among war displaced in Chechnya and Ingushetia. Confl Health 1-4

Diez Roux AV (2001) Investigating neighborhood and area effects on health. Am J Public Health 91(11):1783-1789

El-Khazen F (2000) The breakdown of the state in Lebanon, 19671976. London, I.B. Tauris in association with Centre for Lebanese Studies

Fawaz M (2008) An unusual clique of city-makers: social networks in the production of a neighborhood in Beirut (1950-1975). Int J Urban Reg Res 32:565-585

Fawaz M, Peillen I (2003) Understanding slums: case studies for the global report on human settlements 2003-the case of Beirut. Lebanon, UN-Habitat

Ghobarah H, Huth P, Russett B (2004) The postwar public health effects of civil conflict. Soc Sci Med 59:869-884

Habib RR, Basma SH, Yertezian JS (2006) Harboring illnesses: on the association between disease and living conditions in a Palestinian refugee camp in Lebanon. Int J Environ Health Res 16:99111

Habib RR, Mahfoud Z, Fawaz M, Basma SH, Yeretzian JS (2009) Housing quality and ill health in a disadvantaged urban community. Public Health 123(2):174-181

Harpham T (2009) Urban health in developing countries: what do we know and where do we go? Health Place 15:107-116

Illsley R, Svensson P-G (1990) Social inequalities in health. Soc Sci Med 31:223-240

Jacobs DE, Wilson J, Dixon SL, Smith J, Evens A (2009) The relationship of housing and population health: A 30-year retrospective analysis. Environ Health Perspect 117(4):597-604

Jia H, Moriarty DG, Kanarek N (2009) County-level social environment determinants of health-related quality of life among US adults: a multilevel analysis. J Community Health 34:430-439
Karam EG, Mneimneh ZN, Karam AN et al (2006) Prevalence and treatment of mental disorders in Lebanon: a national epidemiological survey. Lancet 367:1000-1006

Khater AF (2001) Inventing home: emigration, gender, and the middle class in Lebanon, 1870-1920. University of California Press, Berkeley

Krieger J, Higgins DL (2002) Housing and health: time again for public health action. Am J Public Health 92:758-768

Lawrence RJ (2006) Housing and health: beyond disciplinary confinement. J Urban Health 83(3):540-549

Leipziger D, Fay M, Yepes T (2003) Achieving the millennium development goals: the role of infrastructure. The World Bank, Washington DC

Lowry S (1991) Housing and health. BMJ, London

Macintyre S, Macdonald L, Ellaway A (2008) Do poorer people have poorer access to local resources and facilities? The distribution of local resources by area deprivation in Glasgow, Scotland. Soc Sci Med 67:900-914

Makhoul J, Abi-Ghanem D, Ghanem M (2003) An ethnographic study of the consequences of social and structural forces on children: the case of two low-income Beirut suburbs. Environ Urban 15:249-259

Muhajarine N, Labonte R, Williams A, Randall J (2008) Person, perception, and place: what matters to health and quality of life. Soc Indic Res 85:53-80

Pederson D (2002) Political violence, ethnic conflict and contemporary wars: broad implications for health and social well-being. Soc Sci Med 55:175-190

Phipatanakul W, Eggleston PA, Wright EC, Wood RA (2000) Mouse allergen, II: the relationship of mouse allergen exposure to mouse sensitization and asthma morbidity in inner-city children with asthma. J Allergy Clin Immunol 106:1075-1080

Pickett K, Pearl M (2001) Multilevel analyses of neighborhood socioeconomic context and health outcomes: a critical review. J Epidemiol Community Health 55:111-122

Poortinga W, Frank D, Dunstan FD, Fone DL (2008) Neighborhood deprivation and self-rated health: The role of perceptions of the neighborhood and of housing problems. Health Place 14:562575

Riva M, Gauvin L, Barnett TA (2007) Toward the next generation of research into small area effects on health: a synthesis of multilevel investigations published since July 1998. J Epidemiol Community Health 61:853-861

Roberts B, Ocaka KF, Browne J, Oyok T, Sondorp E (2009) Factors associated with the health status of internally displaced persons in northern Uganda. J Epidemiol Community Health 63:227-232

Schmidt M, Kravic N, Ehlert U (2008) Adjustment to trauma exposure in refugee, displaced, and non-displaced Bosnian women. Arch Womens Ment Health 11(4):269-276

Sharara W (1998) Hizbullah State: Lebanon as an islamic society (in Arabic: Dawlat Hizbullah: Lubnan Moujtama'an Islamiyan). Beirut, Dar An-Nahar

Shaw M (2004) Housing and Public Health. Annu Rev Public Health 25:397-418

Shenassa ED, Daskalakis C, Liebhaber A, Braubach M, Brown M (2007) Dampness and mold in the home and depression: an examination of mold-related illness and perceived control of one's home as possible depression pathways. Am J Public Health 97(10):1893-1899

Spengler JD, Jaakkola KJK, Parise H, Katsnelson BA, Privalova LI, Kosheleva AA (2004) Housing characteristics and children's respiratory health in the Russian Federation. Am J Public Health 94(4):657-662

UN United Nations (2008) World Urbanization Prospects The 2007 Revision USCRI US Committee for Refugees. World Refugee Survey 1999-Lebanon 
United States Committee for Refugees and Immigrants, U.S. Committee for Refugees World Refugee Survey 1999 - Lebanon , 1 January 1999, available at: http://www.unhcr.org/refworld/docid/ 3ae6a8cfc.html. Accessed 25 October 2010

Wang C, Abou El-Nour MM, Bennett GW (2008) Survey of pest infestation, asthma, and allergy in low-income housing. J Community Health 33:31-39

WHO Regional Office for Europe (2004) Housing and health, health and environment briefing pamphlet series 41 . WHO Regional Office for Europe, Copenhagen
WHO, World Health Organization (1992). International statistical classification of diseases and related health problems. 10th edn. Geneva

Zabaneh JE, Watt GCM, O'Donnell CA (2008) Living and health conditions of Palestinian refugees in an unofficial camp in the Lebanon: a cross-sectional survey. J Epidemiol Community Health 62:91-97

Zock JP, Jarvis D, Luczynska C, Sunyer J, Burney P (2002) Housing characteristics, reported mold exposure, and asthma in the European community respiratory health survey. J Allergy Clin Immunol 110:285-292 